\title{
TAQIZADEH AND EUROPEAN CIVILISATION
}

\author{
By A.M. Ansari \\ University of St Andrews
}

\begin{abstract}
The leading Iranian intellectual and nationalist Hasan Taqizadeh has been roundly condemned by posterity for his call to Iranians to embrace European civilisation in its entirety without qualification or compromise. Taqizadeh himself later conceded that the form of words he had used were injudicious, but he added that his intention had been to galvanise Iranians out of their self-destructive political stupor and it remains a reality that many of Taqizadeh's contemporaries were supportive of his call to arms. This paper reassesses Taqizadeh's position in the context of his historical and intellectual environment, which it is argued drew heavily from a "Whig" reading of the Enlightenment progress. It shows that Taqizadeh was not alone in drawing on this narrative while maintaining an important distinction between the positive aspects of British political thought and the shortcomings of British policy.
\end{abstract}

Keywords

Taqizadeh; civilisation; Whig; Enlightenment; Britain, al-Afghani; Malkom Khan

In the introduction to a recent collection of Hasan Taqizadeh's writings on "foreign" (i.e. Western) civilisation, the editor took care to warn his readers of the impending dangers of the text before of them. ${ }^{1}$ Taqizadeh, among the leaders of the Constitutional movement of 1906, was a political activist and intellectual perhaps most famous, if not notorious, for his call to arms in the pages of the nationalist organ, Kaveh, directing Iranians to embrace the West wholeheartedly and without reservation. Taqizadeh's uncompromising stance had long been condemned, even by his intellectual fellow travellers as at best, overdone, and at worst treasonous. ${ }^{2}$ The editor of this particular edition by all accounts leaned towards the latter interpretation, taking the opportunity to draw on a long excerpt from Jalal Ale Ahmad, in order better to situate Taqizadeh as a prime example of the "Westoxicated" individual. It was not, to be sure, entirely Taqizadeh's fault but a consequence of his situation. He was in the end a victim of his desperate circumstance, which made him vulnerable to the manipulations of others, not least the "politician" Edward Browne. How else, reflects the editor, can one begin to understand Taqizadeh's willingness to discard the sacred clothing of the clergy and don instead "the tie and ironed suit", along with eau de cologne, and take a German wife. ${ }^{3}$

Taqizadeh 1379/2001: 148.

For example, Aryanpur 1350/1973: 232.

Alizadeh, introduction to Taqizadeh 1379/2001: 13-14.
This association with Edward Browne makes Taqizadeh emblematic of the infected "Oriental", uprooted from his native culture, cast adrift in an alien world he seeks to transpose onto his own. ${ }^{4}$ Unsurprisingly it is a reading of Taqizadeh that, with occasional nods to his obvious intellect, remains popular among proponents of Edward Said's later polemic on "Orientalism". Many have since come to his defence, deploring the lack of context with regard to the particular situation that Iran found itself in at the end of the Great War, and the fact that contrary to received wisdom, Taqizadeh's call to arms had enjoyed the sympathy of many contemporaries who shared the belief that something had to be done to galvanise an otherwise dormant populace - and perhaps more pointedly, a political elite-into action. ${ }^{5}$ This is Taqizadeh as a political activist, whose youthful enthusiasm for action got the better of his own common sense. ${ }^{6}$ Indeed, Taqizadeh's rehabilitation had reached such a stage that even those who might be considered naturally antithetical to his project and political leanings, excuse it, not on the basis of unfortunate political expediency, but of simple-if uncharacteristic-ignorance. Taqizadeh was of course acutely aware of the storm he had caused, and the lectures included in the volume were

4 Praise from Ann Lambton would only add to such a perception; see Lambton 2003: 109-11.

5 Behnam 2003: 82.

6 See Katouzian 2012: 195-213. 
his attempt in later life to explain and in part atone for the language (if not the sentiment) he had used and the misinterpretations that had resulted. ${ }^{7}$ Indeed, the evidence suggests that Taqizadeh was far from naïve or ignorant in the substance of his ideas or his appreciation of "European civilisation", and that on the contrary he was rigorous and precise in his application of these ideas and concepts. Yet, he was at the same time acutely sensible to the plight of his country and often struggled to communicate these ideas in a manner that would energise his countrymen into action. ${ }^{8}$ It was this inherent contradiction between complex ideas and popular communication that he would frequently struggle to reconcile, and his tendency to exaggerate for political effect echoed the polemics of one of his political and intellectual heroes, Jamal al Din al-Afghani. Like Afghani, Taqizadeh is best understood as a man of the Enlightenment, which in its philosophy of emancipation harboured elements of political iconoclasm. ${ }^{9}$ It is in the context of this particular intellectual inheritance that Taqizadeh's ideas and motives can be best understood, in particular the importance he gave to education - in the broadest sense of that word-, the acquisition of manners, and above all "civilisation".

In order better to understand and appreciate this inheritance we need, however, to review our understanding of the intellectual movement known as the Enlightenment, which transformed European political and social relations from the end of the seventeenth century. For some, any association with the "European Enlightenment" is condemnation enough for a generation of political thinkers who are somehow

See for example, Matin-Asgari 2014: 57.

8 As Vatandoust notes (1977: 53), Taqizadeh felt that his ideas were constantly misinterpreted.

9 See, for example, Taqizadeh's reflections in his lectures to Columbia University on "The History of Modern Iran" in Taqizadeh 1979: 205; see also 1350/1972: 75-83. Afghani was a remarkably popular figure among the early nationalists (who noted that he was also known as Asaadabadi) describing him as the "great philosopher of Iran"; Iranshahr 1293/1923, III/1 and 2: 18; see also Iranshahr 1293/1923, II/1, 18 September : 46-52. Iranshahr reprinted one of Afghani's lectures on the subject of education (largely in praise of philosophy) delivered at the Albert Hall in Calcutta in 1872 (Iranshahr 1925, III/4, 15 February: 193-203. Similarly, in the journal Ayandeh 1927, 2, 5 July: 395-401, edited by Mahmoud Afshar. The belief that Afghani was in fact Iranian was well known and was articulated by Nizam al Islam Kirmani in "History of the Awakening of the Persians", quoted by Browne 1910: 4, n. 1. held responsible for the failures of European civilisation in the twentieth century. The Enlightenment, as a somewhat monolithic intellectual movement, is held responsible - among other things - for imperialism and the development of race theories through its promotion of ideas of polygenesis. ${ }^{10}$ Perhaps the most succinct and consequential articulation of this negative reading was by Edward Said in his influential critique Orientalism. ${ }^{11}$ Yet as some more recent sympathetic scholars are keen to point out, the ideas of the Enlightenment were neither uniform, nor can they sensibly be straitjacketed into "national" types. The philosophes of the late seventeenth and eighteenth centuries felt themselves to be heirs of a far more cosmopolitan tradition, which in some cases could be traced to the classical Islamic world. ${ }^{12}$

These were not ideas bound by religion or geography, but were common to humanity and sought to improve the welfare and position of mankind by a "revolution of the mind" achieved through education, broadly conceived and applied. This was education that was both practical (scientific) and ethical-the improvement of manners in order to attain a civilised state. Civilisation thus conceived was not a state of being but an aspiration to be sought, and what could be achieved could at the same time be lost. Although informed by classical conceptions, this state of civilisation was not inherently limited to a particular group, region, or biological "race", such that even at the turn of the twentieth century, when race theories were arguably becoming more popular, Japan could be considered, by virtue of its European inspired reforms, part of the civilised world. ${ }^{13}$ What mattered was education, and while ideas of race began to dominate the minds of some on the European continent, a different and more liberal narrative of the Enlightenment held on in what might be termed the British or Anglo-American tradition. This important distinction became apparent in an intellectual confrontation between British and German academics during the Great War, after the latter had protested at the deployment of "Asiatics" on the Western Front. ${ }^{14}$

10 See in this regard, Beasley 2010: 9-11, and in considerably more detail, Kidd 2006: 79-120.

11 Said 1978: 3. See in response to this, Bonakdarian 1993: 7-31.

12 See for example, Israel 2006: 615-40.

13 Pistor-Hatam 1996: 111.

14 Greenwood et al. 1915: 9-10; see also Zimmern's essay (1915: 363-64) in the collection on German and British ide- 
It nicely mirrors an earlier confrontation between the French philosopher Ernest Renan and Jamal al Din al-Afghani, who had responded to Renan's criticism of "Semitic" religions in an articulate riposte that won him the praise of Renan. Afghani's response to Renan, which appeared in the Journal des Débats in 1883, agreed with Renan that, "the Muslim religion has tried to stifle science and stop its progress" and that it had "succeeded in halting the philosophical or intellectual movement and in turning minds from the search from the scientific truth." Moreover, he added, "I know all the difficulties that the Muslims will have to surmount to achieve the same degree of civilization, access to the truth with the help of philosophic and scientific methods being forbidden them." But he stressed, it was not always thus, and to blame the Arabs as a people for the failures of the few was unjust. It was emphatically not the fault of a people but of a mindset, and there had been times in the past when the Catholic Church had been just as opposed to knowledge: "If it is true that the Muslim religion is an obstacle to the development of sciences, can one affirm that this obstacle will not disappear one day? How does the Muslim religion differ on this point from other religions?"15 Afghani's response was as much (if not more) a call for education and philosophical inquiry, as a defence of the Arabs and of Islam as a faith-and in this he reflected his own intellectual sympathies - which was unsurprisingly well received by the philosophes of Europe, who regarded Afghani as an intellectual fellow traveller. Another central aspect of his argument, of course, was the possibility of change, improvement, and progress-key elements of the Enlightenment narrative.

One of the attractions of Enlightenment thought was that it held out the possibility of progress for all, subject to the adoption of certain methods and attitudes, to that revolution of the mind that opened it to enquiry and investigation. Iranian travellers to Britain in the early nineteenth century became attuned to this message. British success was not attested by simple force of arms but by political and social stability facili-

als of civilisation, the former focusing on the imposition of a "superior culture". Indeed the application of the concept of civilisation enjoyed by this stage was quite distinct in Britain and Germany. See also G.N. Curzon's justification for British rule in India in Gilmour 1994: 166.

15 See al-Afghani's “Answer of Jamal al-Din to Renan" in Journal des Débats, 18 May 1883 (transl. by N. Keddie) in Keddie 1983: 183. tated by the rule of law, which guaranteed certain freedoms, such that Fath 'Ali Shah conceded in discussion with Sir John Malcolm that George III seemed to be little more than the first magistrate of the country and that, "Such a condition of power has permanence but it has no enjoyment: mine is enjoyment... but then it has no permanence." ${ }^{16}$ Indeed, when three Qajar princes travelled to Britain in 1836 they were struck by the political realities they encountered and were reminded by their hosts that in times gone by, their own situation was much more chaotic but they had since adapted, learned, and applied both law and by extension order. ${ }^{17}$ It was this stability that allowed for scientific advance and no effort was spared by the hosts in showing off both their political and scientific achievements. For British observers of Iran in this period, the problems of the country lay in its political structures (specifically the absence of institutions) not in the people themselves, more so because the Persians for all their flaws were an inherently "civilised" people who in Gibbon's memorable phrase had been "long since civilised and corrupted". ${ }^{18}$ In other words the Iranians had become decadent. Gibbon's monumental Decline and Fall was of course a masterful study of the rise and fall of civilisations and not least of the impact of religion. It both symbolised and extended a particular-Whiggish-Enlightenment narrative about the possibilities of change that was naturally to prove attractive to reformers elsewhere. ${ }^{19}$

One of the ways in which these ideas were imparted was through the membership of Masonic lodges, which the Iranian political and intellectual elite, small as it may have been at this time, appeared to have embraced with enthusiasm. The three princes certainly did not disguise their pleasure at having been asked to join "this most noble society". ${ }^{20}$ There were obvious attractions of belonging to an intellectual fraternity in which they might be received as equals, but it is also worth remembering that the Masons retained a reputation for iconoclasm and anti-establishment-ism, especially on the continent. There was after all a rea-

\footnotetext{
16 Malcolm 1827: 215.

17 Mirza 1835: 28-29.

18 Pocock 2005: 24. As Pocock notes (2005: n. 19), it was thus possible to be - in the language of the time - "barbarian and civilized at the same time".

19 For a discussion of Gibbon's ideas see Furet 1976: 209-16; see also Trevor-Roper 2010: 129-43.

20 Mirza 1835: 123. They translate Freemason literally as azad-banna.
} 
son they had chosen to remain secret societies, wary of the wrath of organised religion and latterly, the increasingly powerful reactionary state. ${ }^{21}$ Joining the Masons might facilitate access to ideas and networks but tradition dictated that it by no means implied subservience to the state, even the British state. Adherence to a political philosophy did not entail loyalty to a particular policy. It was thus entirely possible to find the political philosophy behind the contemporary British state - constitutionalism, rule of law, the Whiggish conception of progress - attractive, while remaining critical of policies. Indeed the British were good at it - and appeared to encourage it - themselves. ${ }^{22}$

Even those who were ostensibly part of the machinery of government found themselves unable to reconcile their ideals with the practicalities of politics, as the diplomat Edward Eastwick found in a discussion with an Iranian prince charged with protecting Khorasan:

"England professes herself to be an ally of Persia, and yet she pertinaciously opposes measures which are absolutely requisite to secure the Persian frontier. England assumes to be the determined enemy of the slave trade, and has gone to enormous expense to liberate the African races, to whom she is in no way bound save by the tie of common humanity. It is surely, then, inexplicable that England should have never lifted a finger to save or rescue the hundreds of thousands of Persians who are carried off into slavery by the Turkmans. So far from that, England shackles and impedes every effort that the Persian government makes for the protection of its own subjects, and, by expelling Persia from Herat, and even discouraging a friendly alliance between the two countries, renders the tranquillity of Khurasan impossible". "I must confess", added Eastwick, "I thought there was a great deal of truth in the remarks of the prince..." ${ }^{\prime 23}$

A similar if somewhat more angry denunciation was expressed by Jamal al Din al-Afghani in the aftermath of the Tobacco Boycott, in an article which appeared in the Contemporary Review of London in 1892. The piece, entitled "The Reign of Terror in Persia", was prefaced by a sympathetic introduction, which pre-

21 On the importance of Freemasonry to the radical enlightenment and its association with Whiggism, see Jacob 2006 [1981]: esp. 80-111; see also Bayat 2010: 174.

22 On this see Bonakdarian 1993: 10, n. 13.

23 Eastwick 1864: 253-54. sented Afghani to the readership as an "eminent Oriental statesman...a man of cosmopolitan sympathies and encyclopaedic learning." Afghani had reportedly already delivered a lecture on the subject (in French) and the print version left no doubt as to Afghani's contempt for the rule of Naser al-Din Shah, whose recent visit to Britain had apparently elicited praise where, Afghani felt, clearly none was warranted. "Let it be known", thundered Afghani, "that under the present Shah we have no law and of late, I may add, no government." He continued, "A patriarchal government without a written code is tolerable; but neither law nor government, only cruel, rapacious, unscrupulous and sleepless tyranny, that is not tolerable; yet that is our lot." ${ }^{24}$ The people of Iran, argued Afghani, demanded a code of law and expected Britain to help them get one but instead its press and politicians were content to sanitise a tyrant who used every visit to extend his despotism. What is perhaps most striking about this extended protest is not the hypocrisy of British policy, but the sheer frustration that the British would not do more to help.

"What made the Persian believe that England meant to help them? I pray you, did not your Ministers a year or two ago urge upon the Shah a firman granting security of life and property to his subjects. Did not the Shah issue such a firman, and, after considerable pressure and long debate and hesitation, frankly communicate to the Powers? Did not her Majesty [Queen Victoria] upon hearing this express to Malcom Khan her profound satisfaction, and was not your Minister at Teheran regarded as a party to the transaction? All Persians believed that a firman thus issued and communicated to the European Powers gave the Powers, England first and foremost, the diplomatic right to insist upon its due observance, or at least to demand the explanation for any gross violation of it. Well, what followed? I, Sheikh Djemal ed Din, soon after became the natural and respectful mouthpiece of the people's joyful aspirations. I am received with favour by His Majesty, my words are approved, the regeneration of Persia is at hand; law is to be given, life and property are to be safe, our wives and daughters protected from outrage, our bread winners from cruel and ruinous exactions - all is going well. Suddenly I am seized, banished, imprisoned: my friends were imprisoned and tortured, without explanation, without trial...the peoples eyes were opened; they felt

24 Al-Afghani 1892: 238-48 (reprinted in Ridgeon 2005: 5). 
they could place no reliance on the Shah... But their eyes were then to the Powers, to England first and foremost. Now would the British minister, at least, certainly speak one little word at Teheran, if only to ask for some explanation of so gross a violation of the blessed firman. But no not a word!’25

In other words the criticism was more nuanced than one would at first suspect and reflected the conflict between ideals and reality - in this case economic interest - that would continue to pit the application of British policy against the ideals and underlying political philosophy, which many Iranian intellectuals, including Afghani, continued to find attractive. His criticism of the shortcomings of British imperialism would have fell on receptive ears among the many Britons who likewise shared his reservations about the contradictions of policy and ideals, not least Edward Granville Browne, and in this sense just as later the critique of Orientalism would emanate from the heart of the West, so too the critique of imperialism came from within the heart of empire.

Just how far this intimacy extended was reflected in the fact that Afghani, like many of his contemporaries, was an active Freemason, even going so far as to establish his own lodge in Cairo after he found the lodge he belonged to wanting in political activism. Indeed, Afghani was to prove an extremely active Mason, initially belonging to several lodges, and according to some accounts he was encouraged in this interest by the British Vice-Consul in Cairo to affiliate one particularly important lodge with the United Grand Lodge of England..$^{26}$ These ideological sympathies and Masonic associations have subsequently been disguised under a shroud of pan-Islamism for which Afghani was later to become famous, a label that was encouraged by Edward Browne; ${ }^{27}$ and it has often been difficult to chart a direct intellectual inheritance beyond general inspiration between successive generations of thinkers, although there is evidence that Taqizadeh was well aware of Afghani's striking response to Renan which, he notes in a later biographical note, had earned Renan's praise and added to Afghani's reputation. ${ }^{28}$

A much clearer link is provided in the person of Malkom Khan, whom Afghani drew attention to in his

25 Al-Afghani 1892: 12.

26 Kudsi-Zadeh 1972: 27-28.

27 Browne 1910: 1-30. The meaning of "pan-Islamism" has arguably shifted since Browne's articulation.

28 Taqizadeh 1350/1972: 80. aforementioned article as the progenitor of the idea of reform around a code of laws, ${ }^{29}$ and who, Taqizadeh noted in his autobiography, had the most profound influence on his own ideas. ${ }^{30}$ Malkom Khan also, unsurprisingly, features heavily in Browne's own account of the Constitutional Revolution, where he has Wilfred Blunt ${ }^{31}$ describe him as, "the most remarkable man I had ever met, and [I am] more convinced than ever of the superior intelligence of the Eastern mind." ${ }^{32}$ In Malkom Khan, the two strands of ideas and application become more apparent, with his promotion of reform and his establishment of a faramushkhaneh (lit. house of forgetfulness) modelled on the Masons, in which like-minded individuals "could meet to discuss reform ideas with great frankness behind closed doors." 33 Whether this establishment can be considered the first lodge in Iran or not (it had no formal affiliation with any European lodge),$^{34}$ the members were reportedly taught "that social order is founded on ten principles, which were: liberty, security of person, security of property, equality of rights, freedom of the pen, freedom of assembly and the merit system." 35

Moreover Malkom Khan's philosophy may be gleaned from the revelation he made to Blunt, to have sought to establish a "religion of humanity" in Iran. ${ }^{36}$

al-Afghani 1892: 6.

30 Taqizadeh 1990: 26. The other individual noted was Abdol Rahim Talebof, whose Ketab-e Ahmad, a fictional account of the education of Ahmad that was modelled on Rousseau's Emile, sought to popularise many of the ideas articulated by Malkom Khan. By outlining the syllabus, Talebof introduced the reader "to the material achievements and other manifestations of European civilisation..." (Bakhash 1978: 347).

31 Wilfred Scawen Blunt was active in the cause of Arab and Ottoman sovereignty and the end of the British occupation of Egypt; see Bonakdarian 1995: 183.

32 Browne 1910: 38.

33 Bakhash 1978: 7. On the etymology of this peculiar appellation, which Algar has translated somewhat more sinisterly as "house of oblivion", see Algar 1970: 279. As noted here, the term was probably coined in part to reflect the secrecy and "forgetfulness" of the participants.

34 Bakhash 1978: 17.

35 Bakhash 1978: 19.

36 Browne 1910: 38. Malkom Khan claimed 30,000 adherents, a probable exaggeration to which Malkom Khan appears to have been prone, although for our purposes the aspiration is more telling than the numbers. One can speculate from comments like these and their reception, how and why the Bábi movement was so sympathetically received among European intellectuals, not least Browne (1910: 424-29). Azali Bábi influences on the Constitutional Movement 
By all accounts Malkom Khan enjoyed a colourful political career and was given to embellishing some of his exploits, but his writings on the subject of reform most obviously in the "newspaper" he founded when exiled in London was to have a profound influence on a generation of political reformers not least, as we have seen, Taqizadeh. Qanun, or "Law", may best be described as a political pamphlet rather than a newspaper as we might understand it, but we can see it as the forerunner to Kaveh. In its polemics in support of legal reform, were the necessity for the rule of law and the need for individuals to improve themselves - to engage in a revolution of the mind. The mast of the newspaper was subtitled "harmony" (ettefaq), justice ('edalat), progress (taraqi), and the price of the first 19 issues was listed as "sufficient comprehension" (fahm-e kafi). This was changed in later issues to the "condition of humanity" (shart-e adamiyyat), before finally an actual price (1 tuman) was affixed for each issue. The emphasis is laid on becoming virtuous men, in essence "gentlemen" 37 (in the Whig conception of that term), in the service of humanity. ${ }^{38}$ It was the function of religion to provide the ethical basis for this development, and while Malkom Khan, who was Armenian and Christian by birth, did not dwell on the role of the ulema, he suggested that they could be a force for reform. ${ }^{39}$

Malkom Khan had no doubt that the tyranny that befell Iran was due to an absence of laws: "A State without law means the destruction of the world. A state without law means the enemy of the rights of the people. Curses upon a state without law. Shame on those ignorant and dishonourable (bi-ghayrat) people who pay taxes to a state without law." ${ }^{40}$ Although he argued for the establishment of an extended council (described by Browne as a parliament), Malkom Khan's constitutionalism did not extend as far as to argue that a constitutional monarchy would be beneficial to contemporary Iran. This was to be reformed from above, constructed by an elite and enforced by an autocrat. Indeed, what Iran needed was above all order and sound administration, and he exhorted the Shah to be the "Peter the Great" of Iran. ${ }^{41}$ It was sound and

have been addressed in Amanat 2009: 23-54.

37 Adamiyyat might also be more literally translated as "men of honour".

38 Browne 1910: 39.

39 Bakhash 1978:15-16.

40 Qanun, no. 15 (n.d.), p. 1. (translation my own).

41 Bakhash 1978: 10. coherent administration that had made Europe great, and this was what Iran had to adopt, without exception. One could not pick and choose what one wanted, nor could one wait until these secrets of administration were learned, they had to be applied forthwith. There was, in sum, no point in relearning what the Europeans had learnt over the course of 3000 years. "In matters of government we cannot and must not invent anything ourselves. Either we must take the knowledge and experience of Europe as our model, or we cannot take a single step to rise out of our barbaric state." ${ }^{42}$

Such then was the febrile context of Hasan Taqizadeh's political education, and his earlier pronunciations in the heat of revolution echoed the commentaries of his intellectual heroes. A product of the seminary, Taqizadeh had proved a voracious reader and autodidact, learning both French and English in order to devour as many political and philosophical treatises as he could lay his hands on. In his youth he travelled to Baku, Beirut, and Egypt via Istanbul absorbing both published and illicit texts including those of the Young Turks. ${ }^{43}$ His declarations showed a clear debt to those who preceded him, as well as a greater depth of understanding of the European intellectual tradition he was absorbing. In many ways this reflected the reality of a century of gradual engagement with the ideas that had shaped a European civilisation that by his day truly dwarfed the Orient with its political, economic, and intellectual might. Like his predecessors and along with many of his intellectual contemporaries, Taqizadeh had become a Freemason and member of the Iran Awakening Lodge (bidari-ye Iran) ${ }^{44}$ in Tehran, playing a leading role in the triumph of the Constitutional Revolution in 1906, although in the tempestuous developments that followed Mohammad 'Ali Shah's coup, he found himself exiled in 1908. He promptly went to London and divested himself of his turban and gown, acquiring a suit and tie much to the disappointment of his close associate Edward Browne, who had felt that Taqizadeh's appeal for help would have been more effective had he retained a more authentic sartorial style. ${ }^{45}$

Taqizadeh, like his intellectual forebears, had been deeply frustrated at the change in British policy that had effectively given Russia a free hand in dealing

42 Bakhash 1978: 12-13.

43 Taqizadeh 1990: 26-45.

44 Bayat 2010: 179.

45 Bonakdarian 1993: 20. 
with the constitutional movement. His frustration was all the more intense because Britain had been instrumental in the initial success of the Revolution, offering sanctuary to the revolutionaries and despite some early misgivings, accepting a request from the revolutionaries to act as their formal intermediary with the government. ${ }^{46}$ Even when European priorities had dictated a détente with Russia and a more reserved approach to the Constitutionalists, Grey was advising his staff that, "There was no question of taking any joint action against [the] spread of liberal principles in Asia." ${ }^{\prime 47}$ Even the architect of Britain's rapprochement with Tsarist Russia found the consequences for British ideals somewhat galling. Nonetheless the signing of the Anglo-Russian Convention in 1907 and the secret clauses not to interfere in respective "spheres of influence", effectively gave Russia a free hand to crush the revolutionary movement in those areas allocated to her-largely the populated and politically active north (Britain's share of this remarkable agreement, which seems to have been dictated by the priorities of British India rather than British imperial concerns in toto, was Iranian Baluchestan). Such was the faith of Iranian constitutional leaders in the support of Britain to counteract the Russians that even one of the leading mojtahids, Sayyed 'Abdullah Behbahani, had written repeatedly to the British chargé d'affaires in Tehran for financial and political assistance. ${ }^{48}$

This was the context of Taqizadeh's "Appeal to England" issued in 1908, ${ }^{49}$ which had echoes of Afghani and sought with perhaps less anger and more emotion, to embarrass British officials into action. The Appeal, which was privately printed by Cambridge University Press in October 1908, has all the hallmarks of having been the result of a close collaboration with Edward Browne, including an appeal to British interest (commerce) and fear of Russia, which had grown dominant as a consequence of British neglect (a theme that lay at the heart of Lord Curzon's Persia and the Persian

46 "General Report on Persian for the year 1906: Sir Cecil Spring-Rice to Sir Edward Grey", dated 29 January 1907, p. 6, reprinted in Burrell, Vol. III 1997: 78.

47 Bonakdarian 2006: 52. The complex British relationship with Iran in the crucial period is excellently laid out in Bonakdarian's book; see also the comments of Hardinge to Grey dated 3 January 1906, p. 10, reprinted in Burrell, Vol. II, 1997, 494.

48 Bonakdarian 200653.

49 Taqizadeh 1977: 451-62. The Appeal is signed by both Taqizadeh and Motazed ed Saltana.
Question, and would have been immediately familiar to any British statesman). Although Russian influence reigned supreme at the Persian court, Taqizadeh assured his readers that, "England has the sympathy and admiration of the Persian people, who had an ancient and almost hereditary belief in the civilization of the French and English, while they regarded the Russians as semi-civilized barbarians." Taqizadeh detailed the means and ways in which the Russians were interfering with the progress of the constitution and argued that at the centre of autocracy, was the "ancient foe of all liberal ideas". Not only did the Iranian parliament "in some measure" owe its existence to England, "The Persian Constitution... was in an especial sense the spiritual child of Great Britain". It was because of this that British inaction seemed inexplicable to Taqizadeh and his fellow revolutionaries, not that they stressed they wanted British help for the sake of it, or to draw Britain into a wider domestic struggle, but because Britain had left the field open to the Russians to intervene. This "betrayal" was haemorrhaging British influence in Iran as Iranians lost their faith in Britain. He ended on a thunderous note:

"For, we repeat once more, with confidence and certainty, the interests of the Persian people and of England are identical, and if the reactionaries triumph, all England's influence in Persia, both political and commercial, is at an end, and the Russian spirit in a Persian body will be the autocrat of Persia...The Persian Constitution came into being under the auspices of England, and is England's spiritual child. For a century the Persians have regarded England as their friend, and today their hopes are fixed on her alone. And so we, a little while ago like yourselves Members of a National Assembly (now alas! destroyed by violence), but now exiles who can only hope to help our country by arousing your sympathy, to seek which we have come so long a journey, make our appeal to you on behalf of our beloved land, and on behalf of the liberties and laws whereby alone her welfare and even her independent existence can be secured, in this place, whither for so long the oppressed have turned for help, and which is the fulcrum of all free institutions and the ancient home of Liberty."

Taqizadeh was of course eventually to be disappointed, and in his frustration with the British and during the Great War he, along with a number of colleagues, relocated to Berlin where they launched the influential 
nationalist newspaper Kaveh. The newspaper was run in two separate series, the first of which - published during the war-tended to pay all due reverence to their German hosts. But it was the second series started after the war that was to prove more influential in terms of prescriptions and advice for the reconstruction and resurrection of Iran. It has been conjectured that this sojourn in Berlin transformed Taqizadeh and his colleagues from Enlightened liberals (Whigs) into nationalists in the continental mould, but this is not reflected in Taqizadeh's subsequent associations and affiliations, which remained resolutely British, nor does it reflect the reality that Berlin remained then and for many years afterwards, among the most liberal parts of the German Reich. The important point to note is that Taqizadeh remained very much part of a tradition of Whig activism which drew its inspiration from a singularly British Enlightenment along with a legacy of activism that could be traced back to Afghani and Malkom Khan. If the Persian Constitution was the spiritual child of Britain, then Kaveh was the spiritual child of Qanun, and contrary to his subsequent reputation, Taqizadeh's language was to be more temperate and refined than that of his predecessors, especially when one considers the context of his rage.

Despite pronouncing itself neutral during the Great War, Iran found itself a battlefield for others as Russian, Ottoman, and British troops heedlessly marched their troops across Iranian sovereign territory in search of advantage and in the protection of particular interests. Were that not bad enough, German agents conspired to manipulate a political process that seemed only too receptive to political overtures (often breaking their own avowed neutrality in the process), while Wilhelm Wassmuss - the German T.E. Lawrence - successfully incited the tribes of southern Iran to mobilise against British occupying forces. For Iranian constitutionalists who had laid so much store on the success of the Constitutional Revolution to establish a stable, legal government for the welfare of an Iranian commonwealth, the situation they faced was nothing short of catastrophic. Not only was any form of government seemingly absent-with devastating consequences for the social and economic fabric of the country - but the "virtue" that was meant to characterise this new "republic of laws" was clearly in short supply. Although it would be natural for successor governments, in their efforts to establish order and justify the measures taken to achieve it, to exaggerate the state of "chaos" that afflicted Iran, it would also be fair to say that the situation as regards the Iranian state had rarely (and certainly not in recent memory) been so poor. ${ }^{50}$ In this context, Taqizadeh's sense of urgency was understandable.

It was in this context also that Taqizadeh first drew the attention of his readers to the necessity for Iranians to adopt the ways of the Europeans without reservation, a call to arms that would come to haunt him and which he admitted on reflection some years later, had erred on the side of recklessness, even if his intention had been, in his own words, to throw a "grenade" into the hitherto stultifying political discourse of the day. ${ }^{51}$ It says much of the sense of desperation shared by many intellectuals at the time that in stark contrast to the opprobrium that was to be heaped upon him by subsequent critics, his contemporaries largely applauded him, even if some felt that the manner in which he had expressed himself was less than subtle. ${ }^{52}$ Interestingly, most appear to have focused on the single slogan highlighted in bold in 1920, uncompromisingly calling for Iran to become outwardly and inwardly, materially and spiritually, European (Iran bayad zaheran va batenan, jesman va rohan farangi maab shavad o bas). ${ }^{53}$ Taqizadeh later noted that this phrase was in fact not his but that of an Ottoman Kurdish thinker, Dr 'Abdullah Jodat (who he remarked had perhaps become too Francophone for his own good), ${ }^{54}$ and noted that the word farang itself was both a little too archaic and broad for his more specific purposes. Indeed in the pages of Kaveh itself, once on the very same page (if on a different column) as the notorious call to arms, and again a year later, Taqizadeh quite specifically articulated the same argument with reference to "European civilisation". The phrase has therefore been articulated at least three separate times, with the most quoted version most likely a paraphrasing from another thinker altogether, while the version outlined in 1921 is the most temperate and refined of all three.

In its longer articulation in the 1920 edition, Taqizadeh takes care to underline his demand which is

50 See in this regard, Bast 2009: 55-68.

51 Taqizadeh 1379/2001: 28.

52 Behnam 2003: 81-82.

53 Kaveh 22 January 1920: 2, col. 2. Atabaki argues persuasively that the word ruhan in this context would be better translated as "mentally". It would certainly conform better to Taqizadeh's preoccupation with education; see Atabaki 2008: 48.

54 Taqizadeh 1379/2001: 30. 
the acceptance and promotion of the civilisation of Europe without reservation, and adds for good measure that the surrender to Europe must be absolute as well as the acquisition of the manners, culture, and science of farangistan without qualification, except that it was noted in parentheses, almost as if he had realised a little too late that his call erred on the extreme side, with regard to language. ${ }^{55}$ This caveat was of course significant, given the importance of language to the conception of Iranian identity and culture and in this respect, even in this early robust outing, the call to arms had already been qualified and restricted in important ways. By January 1921, the message remained but tempers had calmed considerably and for the first time Taqizadeh fully contextualised his demand. ${ }^{56}$ It is in this issue of Kaveh that the 23 prescriptions (17 essential and a further six desirable) for the revival of Iran are laid out in full and the first demand is for universal public education and self-awareness, followed by a demand for the publication of useful books and the translation and publication of Western books. Few statements articulate the driving ideology of the Enlightenment than these demands for mass education and self-awareness. It is only by point 3 that we come to the appeal for the adoption of European civilisation and here the statement is stripped of the more excessive rhetoric of the previous year's edition. Here Taqizadeh simply states, "The acquisition of the principles, culture and traditions of European civilisation [this last phrase is underlined for effect] and its acceptance without reservation (aghaz-e osul va adab va rosum-e tammadon-e europai va ghabul an belashart)". The remaining prescriptions are an ad hoc mixture of the abstract and the practical with calls for the preservation of the unity of the nation and protection of the language from "corruption", the promotion of physical exercise, a war against disease, freedom for women, and a war against lying and ambiguity. Critics of Taqizadeh have been less exercised-if indeed they have noticed at all-by his 15 th prescription to "rid ourselves of the shameful practice of unnatural love", which he considered "was a major obstacle to civilization". The call to emulate Europe is shorn of its appeals to the spiritual and the material, or indeed to any call for "absolute surrender", suggesting that Taqizadeh (perhaps on receiving feedback) decided that the sentiment would be more effective if the expres-

\footnotetext{
55 Kaveh 22 January 1920: 2, col. 1.

56 Kaveh 11 January 1921: 2.
}

sion was toned down. That he underlined the phrase "European civilisation" in the third and final rendition of the statement suggests also that he sought to draw specific attention to the particularity of his call, and we know that on later reflection he felt the original term, farang, to be too broad for his purposes.

Taqizadeh's own education, his intellectual inheritance and sympathies, as well as his membership of the Freemasons, all suggest that he had a very good idea of what he understood by the term when he used it, and that its use was deliberate and defined. He must have been aware, for example, given his six years in Germany at the height of the Great War, that the term "civilisation" had developed a distinct and separate meaning in the Germanic world (and further east), where the term "culture" had come to occupy the place of civilisation in the Franco-British intellectual establishment. ${ }^{57}$ While British usage had also developed two distinct if inter-related meanings by the nineteenth century, it still held, in the mind of many intellectuals a powerful association with progress and the cultivation of civility, which could be achieved through dedicated education. As a process of mental and "spiritual" improvement, it of course lent itself to a stage theory of history, one that was perhaps best expressed by Hegel's theory of the unfolding of the consciousness of freedom and the "cunning of reason". Hegel's confidence in the progress of "history" from - it should not be forgotten - the Persians ("in Persia first arises that light which shines itself, and illuminates what is around; for Zoroaster's 'Light' belongs to the World of Consciousness" ${ }^{\prime 58}$ ) to the Greeks and Romans, to be triumphantly inherited by the Germanic people, was provided with a useful qualification by Gibbon's Decline and Fall which pointedly reminded its readers that the direction of travel could always be reversed. It was the recognition of this important fact that made the Enlightenment narrative of education so powerful and redemptive. If progress could be lost, it could also be rediscovered and regained. After all European civilisation was proof of this, as it had moved from the Dark Ages to rebirth and enlightenment. There was nothing, in its inception at least, that was peculiarly European about this process. This was a powerful narrative of redemption and emancipation that was to prove immensely attractive to those less fortunate.

It was perhaps less in his appreciation of the re-

\footnotetext{
7 On this distinction see Braudel 1993: 4-6.

58 Hegel 1956: 173.
} 
generative qualities of "civilisation" that happened to be currently enjoying a resurgence in Europe, that Taqizadeh could be open to criticism than in his almost unquestioning acceptance of the grand narrative of that European ascent. This was, in fairness to Taqizadeh, neither unusual nor unexpected given the emphatic dominance of European civilisation and science by the turn of the twentieth century, and indeed both Afghani and Malkom Khan had accepted that Europe had inherited the mantle of civilisation that in previous ages may have lain elsewhere. It is also true that Taqizadeh would not have been aware of the revolution on historiography that has since occurred, and to which his own considerable research undoubtedly contributed. Nevertheless, by the turn of the twentieth century a narrative of ascent, both general and particular, had been well established and Taqizadeh was to adopt both.

Indeed, drawing on a particularly Whiggish interpretation of history, the introduction to his party's constitution, drawn up in 1909, stated categorically that the twentieth century was the equivalent of the seventeenth century in the West; a period of renewal when feudalism and absolutism would be swept away by capitalism. ${ }^{59}$ Later, in the aftermath of the Great War and faced with the stark reality that there was no coherent central government whatsoever, Taqizadeh returned to the European narrative to see what lessons might be found there for Iran. The key, echoing his intellectual mentor Malkom Khan, was to ensure first and foremost the establishment of order and good administration, enablers that could then allow the benefits of the Enlightenment to spread to wider society. What Iran needed, Taqizadeh concluded in a commentary written some months after the coup of 1921 (led in part by Reza Khan), was "Enlightened despotism (estebdad monavar)", of the type that transformed European governments in the eighteenth century. Despite the widespread admiration for the French Revolution and Napoleon, a "Napoleon" was neither sufficient nor viable in a country as reactionary as Iran. What was needed, in further echoes of Malkom Khan, was an Iranian "Peter the Great" ${ }^{60}$ What was demanded was a revolution from above led by an enlightened ruler who could transform society (Peter the Great, it was helpfully pointed out, had forbidden the wearing of beards) as well as the political fortunes of the country. It was not, as Taqizadeh was careful to point out, a

59 Behnam 2003: 79.

60 Kaveh 4 September 1921: 3. matter of desirability - constitutionalism remained the best form of government— but of necessity. ${ }^{61}$

On the larger question of the "Grand Narrative" as outlined above, Taqizadeh also found himself in broad agreement with the narrative of civilisation developed by European (Enlightenment) thinkers, and indeed as his activism gave way to scholarship, it was on these longer narratives that his attention became fixed. For Taqizadeh, civilisation, essentially an urban phenomenon which emerged in the Greek world, was protected and nurtured by Islam, while Europe languished in its "Dark Ages", before returning to the "Renaissance" West from whence it proceeded to flower and progress. ${ }^{62}$ Indeed for Taqizadeh, although classical Islamic civilisation harnessed the ideas of the Greeks it never surpassed their achievements, which to his mind remained an extraordinary period in human civilisation. There were nonetheless, in Taqizadeh's view, four distinct ages in human civilisation: the emergence of writing from 4000 to about $700 \mathrm{BC}$; the era of Greek civilisation from the sixth century BC to around the third century AD; the era of classical Islamic civilisation from $c$. the ninth century $\mathrm{AD}$ to $c$. the thirteenth century $\mathrm{AD}$; and finally the era of Western civilisation from 1453. These were, as noted above, fundamentally intellectual ('elmi) ages - the ages were not necessarily contiguous - which provided the environment from which other achievements of civilisation could emerge. Yet none of the other things could be achieved without the philosophical and scientific foundations upon which they might be built. It is also worth remembering here that the concept of a distinct "Islamic" civilisation where these "humanistic" ideas were nurtured and developed, was very much a product of this Enlightenment narrative, having its basis in the cosmopolitan outlook of early Enlightenment thinkers before being further articulated and clarified in the nineteenth century. ${ }^{63}$

What was perhaps striking in Taqizadeh's adoption of this intellectual stage theory of history was the absence of any key role for a distinctly Iranian civilisation, and this seems to have irritated a number of his more youthful critics who protested at his championing of Greek thought over that of the Persians. Indeed in his later historical writings, Taqizadeh laid far more emphasis on the importance of Islam than his earlier

61 See Vatandoust 1977: 205.

62 Taqizadeh 1379/2001: 31-37.

63 See, for example, Israel 2006: 615-40. 
activism might have suggested, and there was little obvious Persian chauvinism in his historical assessments, to the point that one could speculate that he may have been compensating for an earlier radicalism that he felt may have been, in part, responsible for the sort of chauvinism he now witnessed among the faux Iranian nationalists he so detested and had bitterly warned about. ${ }^{64}$ In one exchange, for example, Taqizadeh found himself challenged by a youthful critic who sought to argue that the idea of "justice" was clearly so prevalent in Iranian history that it must have predated anything the Europeans (or indeed the Greeks) could have conceived. Taqizadeh gently responded that words and meaning were quite different and it was erroneous to suggest that the meaning of justice in the ancient world was the same as it is today. ${ }^{65}$ At the same time, it is important to bear in mind that the concept of Islamic civilisation clearly did not preclude the important contributions of the Iranians, who in a narrative tradition that would even be endorsed by the clergy, were regarded as central to the triumph of that civilisation. ${ }^{66}$

Be that as it may, Taqizadeh was emphatic on the importance of Greek civilisation and the ideas they had generated and passed on, ultimately to the Europeans. Greek civilisation, Taqizadeh argued, was a powerful light that, like the rising sun, had subsumed all other stars. ${ }^{67}$ It was a civilisation of science and ideas, not simple material achievements, and when he had talked of adopting the civilisation of Europe, he did not mean its superficial (material) achievements, but the core ideas that had shaped and liberated it. This could only be achieved through mass education. Fundamentally, Taqizadeh argued, it was about the absorption of the idea of freedom. ${ }^{68}$ A self-confident free people had nothing to fear for their identity from an engagement with the ideas of others, as witnessed by the Japanese. Nor did this engagement with progress preclude a fierce adherence and conservatism to one's own values and culture, as shown by the British. ${ }^{69}$

64 Taqizadeh warned about the emergence as he saw it of the professional patriot-the vatan-chi-in Kaveh, 17 July 1920: 3. See also his response to a question in Taqizadeh 1379/2001: 100-1. Among his more popular histories was Az Parviz ta Changiz (1382/2003: 235).

65 Taqizadeh 1379/2001: 101-3.

66 Most notably Ayatollah Motahhari. For an analysis of his views see Aghaie 2009: 245-53.

67 Taqizadeh 1379/2001: 35.

68 Taqizadeh 1379/2001: 53.

69 Taqizadeh 1379/2001: 57-58.
It is perhaps in his discussion of the idea of freedom that Taqizadeh's philosophy - and debt to the Whiggish narratives of the Enlightenment - shines through. Taqizadeh acknowledges that this "celebrated word" has been much discussed, but of course the purpose and beneficiaries of political, civil, and spiritual freedom are the general populace, a reality that was first appreciated by the Athenians and then sporadically by the Romans. The Athenian inheritance, however, was only truly appropriated by the Europeans, and freedom as we understand the term today, first emerged in the constitutional limitations on power imposed in the thirteenth century in England (presumably the Magna Carta and its consequences), and then much later in France, during the Revolution of $1789 .{ }^{70} \mathrm{He}$ added for good measure that freedom was the greatest blessing bestowed by God upon man, and without it, there could be no growth in thinking and wisdom. ${ }^{71}$ Freedom was the foundation on which true patriotism and the nation could be built. Love of country could not be imposed from above, only nurtured from below, and Europe proved that neither language nor race were the building blocks of a nation. Real-civic - nationalism, could only be rooted in the fertile soil of freedom and justice. ${ }^{72}$ Few statements better encapsulate the Enlightenment project.

\section{A.M. Ansari \\ University of St Andrews \\ [add full address and e-mail}

\section{Bibliography}

al-Afghani, Jamal al Din 1892. "The Reign of Terror in Persia", The Contemporary Review 61: 238-48. (Reprinted in L. Ridgeon (ed.), Religion and Politics in Modern Iran, I.B. Tauris, London, 2005).

Aghaie, K.S. 2009. "Islamist Historiography in Post-Revolutionary Iran", in T. Atabaki (ed.), Iran in the 20th Century: Historiography and Political culture, I.B. Tauris, London: 245-53.

Algar, H. 1970. "An Introduction to the History of Freemansonry (sic) in Iran”, Middle Eastern Studies 6/3: 276-96.

Amanat, A. 2009. "Memory and Amnesia in the Historiography of the Constitutional Revolution", in T. Atabaki (ed.), Iran in the twentieth century, I.B. Tauris, London: 23-54.

Aryanpur, Y. 1350/1973. Az Saba ta Nima, s.n., Tehran.

Atabaki, T. 2008. "From Multilingual Empire to modern state",

$\begin{array}{ll}{ }^{70} & \text { Taqizadeh 1379/2001: } 63 . \\ { }^{71} & \text { Taqizadeh 1379/2001: } 64 . \\ 72 & \text { Taqizadeh 1379/2001: } 73 .\end{array}$ 
in H. Katouzian and H. Shahidi (eds.), Iran in the 21st Century, Routledge, London:

Bakhash, S. 1978. Iran: Monarchy, Bureaucracy and Reform under the Qajars: 1858-1896, Ithaca Press, London.

Bast, O. 2009. "Disintegrating the 'Discourse of Disintegration': Some Reflections on the Historiography of the Late Qajar Period and Iranian Cultural Memory", in T. Atabaki (ed.), Iran in the 20th Century: Historiography and Political culture, I.B. Tauris, London: 55-68.

Bayat M. 2010. "The Rowshanfekr in the Constitutional period", in H. Chehabi and V. Martin (eds.), Iran's Constitutional Revolution: Popular Politics, Cultural Transformations and Transnational Connections, I.B. Tauris, London: 165-92.

Beasley, E. 2010. The Victorian reinvention of Race, Routledge, London.

Behnam, J. 2003. "Taqizadeh va masala-ye tajjadod", Irannameh 21/1-2: 77-89.

Bonakdarian, M. 1993. "E G Browne and the Iranian Constitutional Struggle: from Academic Orientalism to Political Activism", Ir Sts 26/1-2: 7-31.

_ 1995. "Iranian Constitutional Exiles and British Foreign-Policy Dissenters, 1908-9”, IJMES 27/2: 175-91.

2006. Britain and the Iranian Constitutional Revolution of 1906-1911, Syracuse University Press, New York.

Braudel, F. 1993. A History of civilizations, Penguin, London.

Browne, E.G. 1910. The Persian Revolution, Cambridge University Press, Cambridge.

Burrell, M. (ed.). 1997. Iran Political Diaries 1881-1965, vol. 3, Cambridge University Press, Cambridge.

Eastwick, E. 1864. Three Years' Residence in Persia, Smith, Elder and Co., London.

Furet, F. 1976. "Civilization and Barbarism in Gibbon's History", Daedalus 105/3: 209-16.

Gilmour, D. 1994. Curzon, John Murray, London.

Greenwood, A., Seton-Watson, R.W., Wilson, J.D. and Zimmern, A.E. 1915. The War and Democracy, Macmillan, London.

Hegel, G.W.F. 1956. The Philosophy of History, Dover Publications, New York.

Israel, J.I. 2006. Enlightenment Contested: Philosophy, Modernity and the Emancipation of Man, Oxford University Press, Oxford.

Jacob, M. 2006 [1981]. The Radical Enlightenment: Pantheists, Freemasons and Republicans, Cornerstone, Lafayette, LA.

Katouzian, H. 2012. "Seyyed Hasan Taqizadeh: Three lives in lifetime", Comparative Studies of South Asia, Africa and the Middle East 32/1: 195-213.

Keddie, N. 1983. An Islamic Response to Imperialism, University of California Press, Berkeley.
Kidd, C. 2006. The Forging of Races: Race and Scripture in the Protestant Atlantic World, 1600-2000, Cambridge University Press, Cambridge.

Kudsi-Zadeh, A. 1972. "Afghani and Freemasonry in Egypt", JAOS 92/1 (Jan.-Mar.): 25-35.

Lambton, A.K.S. 2003. "Seyyed Hasan Taqizadeh", Irannameh 21/1-2: 109-11.

Malcolm, J. 1827. Sketches of Persia, Longman, London.

Matin-Asgari, A. 2014. "The Berlin Circle: Iranian Nationalism meets German Countermodernity", in K.S. Aghaie and A. Marashi (eds.), Rethinking Iranian Nationalism and Modernity, University of Texas Press, Austin.

Mirza, N.K. 1835. Journal of a Residence in England, (trans. A. Kayat), s.n., London.

Pistor-Hatam, A. 1996. "Progress and Civilization in Nineteenth Century Japan: The Far Eastern State as a model for Modernization", Ir Sts 29/1-2 (Winter-Spring): 111-26.

Pocock, J.G.A. 2005. Barbarism and Religion: Barbarians, Savages and Empires, vol. 4, Cambridge University Press, Cambridge.

Said, E. 1978. Orientalism, Penguin, London.

Taqizadeh, H. 1350/1972. "Seyyed Jamal al Din ma'roof be afghani", reprinted in I. Afshar (ed.), Maqallat-e Taqizadeh, vol. 2, Bist-o panjum-e shahrivar, Tehran: 75-83.

_ 1977. "Persia's Appeal to England" (1908) reprinted in I. Afshar (ed.), Maqallat Taqizadeh, vol. 7, Shokufan, Tehran: 451-62.

— 1979. "The History of Modern Iran", reprinted in I. Afshar (ed.), Maqallat-e Taqizadeh, vol. 8, Shokufan, Tehran: 193-255. 1990. Zendegi-ye Tufani, Elmi, Tehran.

_ 1379/2001. Aghaz-e tammadon-e khareji: tasahol va tasameh, azadi, vatan, melat, Ramin, Tehran.

— 1382/2003. Az Parviz ta Changiz, Donya-ye Ketab, Tehran.

Trevor-Roper, H. 2010. History and the Enlightenment, Yale University Press, New Haven.

Vatandoust, G. 1977. "Sayyid Hasan Taqizadah and Kaveh: Modernism in post-Constitutional Iran (1916-21)", unpublished Ph.D. thesis, SOAS.

\section{Other sources}

Ayandeh

Iranshahr

Kaveh

Qanun 